\title{
Embelin induces apoptosis of human gastric carcinoma through inhibition of p38 MAPK and NF-кB signaling pathways
}

\author{
CHANG-LONG XU, BO ZHENG, JI-HUA PEI, SU-JIAN SHEN and JIAN-ZHANG WANG \\ Department of Gastroenterology, The Second Affiliated Hospital and Yuying Children's \\ Hospital of Wenzhou Medical University, Wenzhou, Zhejiang 325027, P.R. China
}

Received April 19, 2015; Accepted March 11, 2016

DOI: $10.3892 / \mathrm{mmr} .2016 .5232$

\begin{abstract}
Embelin is a small-molecule inhibitor of X-linked inhibitor of apoptosis protein (XIAP), and it induces apoptosis in tumor cells via the inhibition of XIAP. The aim of the present study was to investigate the anticancer effect of embelin on human gastric carcinoma cells and the mechanisms underlying this effect. Cell proliferation of SGC7901 human gastric carcinoma cells was measured using MTT assay, following treatment with embelin $(5,10$ and $15 \mu \mathrm{M})$ on days 1, 3 and 5. Caspase-3 and nuclear factor (NF)- $\kappa$ B p65 activation in SGC7901 cells were assessed using commercial kits. Cellular and nuclear apoptosis were analyzed with an Annexin V-FITC/PI Apoptosis Detection kit and DAPI staining assay, respectively. Phospho (p)-p38 mitogen-activated protein kinase (MAPK), p-inhibitor of NF- $\kappa \mathrm{B}(\mathrm{p}-\mathrm{I} \kappa \mathrm{B} \alpha)$ and $\mathrm{p}-\mathrm{I} \kappa \mathrm{B}$ kinase $\alpha / \beta(\mathrm{p}-\mathrm{IKK} \alpha / \beta)$ protein expression levels were analyzed with western blot assay. In the present study, treatment with embelin decreased cell proliferation, induced caspase-3 activation and suppressed NF- $\mathrm{B}$ p 65 activation in SGC7901 cells. Furthermore, embelin administration reduced $\mathrm{p}-\mathrm{I} \kappa \mathrm{B} \alpha$ and $\mathrm{p}-\mathrm{IKK} \alpha / \beta$ protein expression levels. In conclusion, embelin induces cell apoptosis in human gastric carcinoma through activation of p38 MAPK and inhibition of the NF- $\kappa$ B signaling pathways. It was further suggested that embelin may be used as a potential drug for the treatment of gastric carcinoma.
\end{abstract}

\section{Introduction}

According to the 2012 Chinese cancer registration report and statistics of the World Health Organization, the Chinese population presents a high incidence of gastric carcinoma (1).

\footnotetext{
Correspondence to: Mr. Jian-zhang Wang, Department of Gastroenterology, The Second Affiliated Hospital and Yuying Children's Hospital of Wenzhou Medical University, 109 West Xueyuan Road, Wenzhou, Zhejiang 325027, P.R. China

E-mail: jianzhangwangpaywn@yeah.net
}

Key words: embelin, human gastric carcinoma cell, p38 mitogen-activated protein kinase, nuclear factor- $\kappa \mathrm{B}$
Gastric carcinoma presented the second largest incidence of malignant tumors in China and the third highest rate of mortality; cases of gastric carcinoma and associated mortality account for half the malignant tumor cases worldwide (2). Gastric cancer in China presents high morbidity and mortality rates, and most cases are diagnosed at the advanced stage. The incidence rate of gastric carcinoma in patients under the age of 30 increased from $1.7 \%$ in the 1970 s to $3.3 \%$ at present in China (3).

Nuclear factor (NF) $-\kappa \mathrm{B}$ is a transcription factor observed in various cell types that serves a role in physiological and pathological processes through the $\mathrm{NF}-\kappa \mathrm{B}$-inducing kinase $(\mathrm{NIK}) / \mathrm{I} \kappa \mathrm{B}$ kinase $(\mathrm{IKK}) / \mathrm{NF}-\kappa \mathrm{B}$ signaling pathway $(4,5)$. Previous studies have demonstrated that $N F-\kappa B$ is associated with proliferation, differentiation, apoptosis, invasion and metastasis of tumor cells (6-8). In addition, aberrant activation of $\mathrm{NF}-\kappa \mathrm{B}$ was demonstrated in gastric cancer cells and pathological tissues (9).

$\mathrm{X}$-linked inhibitor of apoptosis protein (XIAP) is an effective caspase inhibitor and the most investigated molecular structure of the inhibitor of apoptosis protein (IAP) family. XIAP selectively binds to caspases-3, -7 or -9 to inhibit their activity and prevent cell apoptosis (10). Embelin is a small-molecule inhibitor of XIAP that binds to the baculoviral IAP repeat 3 structural domain of XIAP and prevents binding to caspases $-3,-7$ or -9 , thus inducing cell apoptosis (11). However, the anticancer effect of embelin in human gastric carcinoma cells and the mechanisms underlying it are poorly understood. The present study hypothesizes that the anticancer effect of embelin induces cell apoptosis in human gastric carcinoma cells through the p38 mitogen-activated protein kinase (MAPK) and $\mathrm{NF}-\kappa \mathrm{B}$ signaling pathways.

\section{Materials and methods}

Chemical reagents. Invitrogen RPMI-1640 and fetal bovine serum (FBS) were obtained from Thermo Fisher Scientific, Inc. (Waltham, MA, USA). MTT was purchased from Sangon Biotech Co., Ltd. (Shanghai, China). DAPI staining assays (cat. no. C1005) and caspase-3 activation commercial kits (cat. no. C1116) were obtained from Beyotime Institute of Biotechnology (Haimen, China). A Pierce BCA Protein Assay kit was purchased from Hangzhou Sijiqing Biological Engineering Materials Co., Ltd. (Hangzhou, China). 
An Annexin V-FITC/PI Apoptosis Detection kit (cat. no. KGA101) was obtained from KeyGen Biotech Co., Ltd. (Nanjing, China). An NF- $\mathrm{kB}$ p65 colorimetric assay kit was obtained from Elabscience Biotechnology Co., Ltd. (Wuhan, China; cat. no. E-EL-H1388c).

Cell culture and cell proliferation assay. The human gastric carcinoma cell line SGC7901 was acquired from the experimental center of the Second Affiliated Hospital of Wenzhou Medical University (Wenzhou, China) and maintained in RPMI 1640 supplemented with 10\% FBS, $100 \mathrm{U} / \mathrm{ml}$ penicillin and $100 \mathrm{mg} / \mathrm{ml}$ streptomycin (Sigma-Aldrich, St. Louis, MO, USA), in a $5 \% \mathrm{CO}_{2}$ atmosphere at $37^{\circ} \mathrm{C}$. SGC7901 cells were seeded in 96 -well plates and treated with embelin (5, 10 or $15 \mu \mathrm{M}$; purity $\geq 98 \%$; Sigma-Aldrich) for 1,3 and 5 days as previously described (12). Cell proliferation was determined using the MTT assay. Briefly, MTT solution (20 $\mu \mathrm{l} ; 5 \mathrm{mg} / \mathrm{l}$; Sangon Biotech Co., Ltd.) was added to each well for a $4-\mathrm{h}$ incubation in a $5 \% \mathrm{CO}_{2}$ atmosphere, at $37^{\circ} \mathrm{C}$. Following incubation, $150 \mu \mathrm{l}$ dimethyl sulfoxide was added to each well and shaken for $20 \mathrm{~min}$ at room temperature. The optical density was determined using a 96-well multiscanner at $570 \mathrm{~nm}$ (ELx808; Bio-Tek Instruments, Inc., Winooski, VT, USA).

Analysis of caspase-3 activity. SGC7901 cells were seeded in 6 -well plates and treated with embelin $(5,10$ or $15 \mu \mathrm{M})$ for 5 days. Following treatment, caspase- 3 activity was assessed using caspase- 3 activation commercial kits. Briefly, cells were prepared in cell lysis buffer for $30-60 \mathrm{~min}$ at $4^{\circ} \mathrm{C}$ and centrifuged at $12,000 \mathrm{x} \mathrm{g}$ for $10 \mathrm{~min}$ at $4^{\circ} \mathrm{C}$. The protein concentrations in the cell lysates were measured with the Pierce BCA Protein Assay kit according to the manufacturer's instructions. Equal amounts of protein were mixed with the Ac-DEVD-pNA reaction buffer and incubated at $37^{\circ} \mathrm{C}$ for $2 \mathrm{~h}$ in the dark. Following incubation, absorbance was measured at $405 \mathrm{~nm}$ with the XL-818 instrument.

Analysis of cell apoptosis. SGC7901 cells were seeded in 6-well plates and treated with embelin $(5,10$ or $15 \mu \mathrm{M})$ for 5 days. Cells were washed twice with ice-cold phosphate-buffered saline (PBS), collected and resuspended in annexin V binding buffer from the kit according to the manufacturer's instructions. Following resuspension, $5 \mu \mathrm{l}$ annexin V-FITC and $5 \mu \mathrm{l}$ propidium iodide were added to the cells, and incubated for $10 \mathrm{~min}$ on ice in the dark. Cell apoptosis was immediately detected using a flow cytometer (Epics Altra; Beckman Coulter, Inc., Brea, CA, USA) to identify annexin V- and/or PI-positive cells.

DAPI staining assay. SGC7901 cells were seeded in 6-well plates and cultured with embelin $(5,10$ or $15 \mu \mathrm{M})$ for 5 days. SGC7901 cells were washed twice with ice-cold PBS and fixed using $0.5 \mathrm{ml}$ paraformaldehyde (4\%; Sinopharm Chemical Reagent Co., Ltd., Shanghai, China) for $30 \mathrm{~min}$ at $4^{\circ} \mathrm{C}$. Cells were then washed twice with PBS and incubated with sodium citrate $(0.1 \%$; Nanjing Jiancheng Bioengineering Institute, Nanjing, China) containing 0.1\% Triton X-100 (Sinopharm Chemical Reagent Co., Ltd.) for $5 \mathrm{~min}$, at $4^{\circ} \mathrm{C}$. Cells were incubated with the DAPI staining assay for $10-15 \mathrm{~min}$ at $4^{\circ} \mathrm{C}$

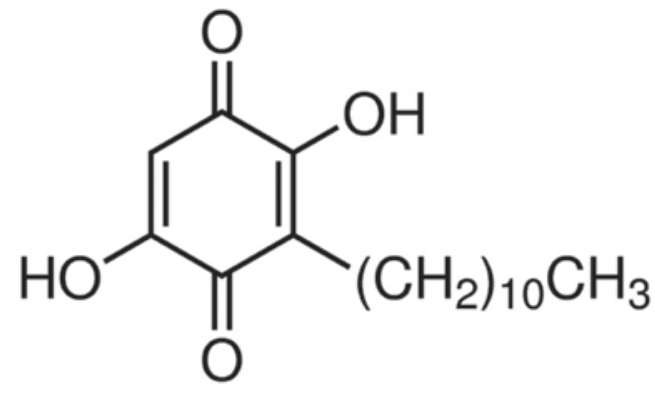

Figure 1. Chemical structure of embelin.

in the dark. DAPI was excited by ultraviolet light to indicate nuclear apoptosis and images were captured with an Axio Observer A1 fluorescence microscope (Zeiss AG, Oberkochen, Germany) at the excitation wavelength of $340 \mathrm{~nm}$.

Analysis of NF- $\kappa B$ p65 activation. SGC7901 cells were seeded in 96-well plates and cultured with embelin $(5,10$ or $15 \mu \mathrm{M})$ for 5 days. NF- $\kappa \mathrm{B}$ p65 activation was measured using the NF- $\mathrm{KB}$ p65 colorimetric assay kit, according to the manufacturer's instructions.

Western blotting. SGC7901 cells were seeded in 6-well plates and cultured with embelin $(5,10$ or $15 \mu \mathrm{M})$ for 5 days. Following treatment, cells were prepared in cell lysis buffer for $30-60 \mathrm{~min}$ at $4^{\circ} \mathrm{C}$ and centrifuged at $12,000 \mathrm{x}$ g for $10 \mathrm{~min}$ at $4^{\circ} \mathrm{C}$. The protein concentrations in cell lysates were measured with the Pierce BCA Protein Assay kit according to the manufacturer's protocol. Equal volumes of proteins were resolved in 10\% SDS-PAGE and transferred to nitrocellulose membranes. Membranes were incubated overnight at $4^{\circ} \mathrm{C}$ with mouse anti-phosphorylated (p)-p38 MAPK monoclonal antibody (1:1,000; cat. no. sc-7973; Santa Cruz Biotechnology, Inc., Dallas, TX, USA), anti-p-IкB $\alpha$ monoclonal antibody (1:1,000; cat. no. ab133462; Abcam, Cambridge, MA, USA), anti-p-IKK $\alpha / \beta$ polyclonal antibody (1:1,000; cat. no. sc-21661; Santa Cruz Biotechnology, Inc.) and anti- $\beta$-actin polyclonal antibody (1:500; cat. no. D110007; Sangon Biotech Co., Ltd., Shanghai, China). Following washing with Tris-buffered saline supplemented with Tween-20, the membranes were incubated with a horseradish peroxidase-conjugated anti-mouse $\operatorname{IgG}$ secondary antibody (1:1,000; cat. no. sc-2380; Santa Cruz Biotechnology, Inc.). for $2 \mathrm{~h}$. Proteins were visualized using enhanced chemiluminescence (Santa Cruz Biotechnology, Inc.) and detected using Quantity One software (Bio-Rad Laboratories, Inc., Hercules, CA, USA).

Statistical analysis. Data are presented as the mean \pm standard deviation of at least three independent experiments and analyzed with SPSS software, version 19.0 (IBM SPSS, Armonk, NY, USA). Differences between groups were analyzed by one-way analysis of variance. $\mathrm{P}<0.05$ was considered to indicate a statistically significant difference.

\section{Results}

Effect of embelin on tumor growth in gastric carcinoma cells. The chemical structure of embelin is presented in Fig. 1. 


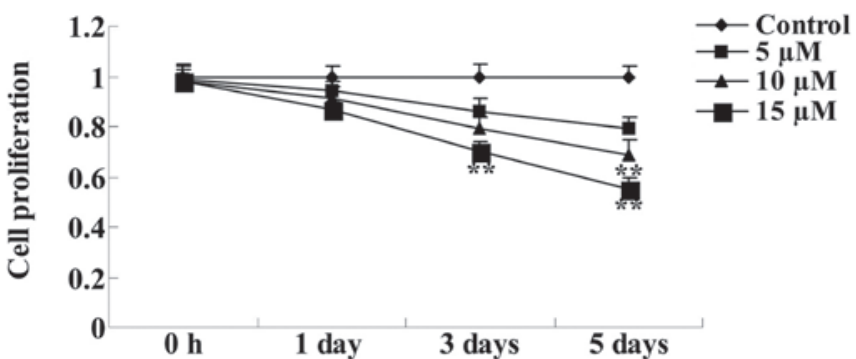

Figure 2. Effect of embelin treatment on the cell proliferation of gastric carcinoma cells. Data represent the mean \pm standard deviation. ${ }_{* * *} \mathrm{P}<0.01$ vs. the control group.

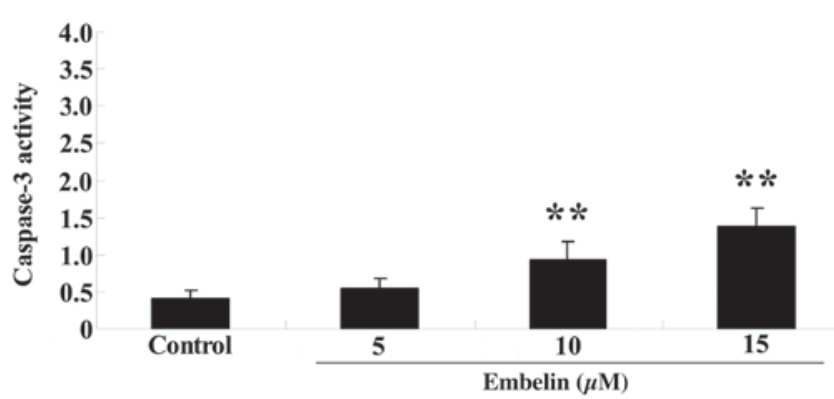

Figure 3. Effect of embelin on caspase-3 activity in gastric carcinoma cells. Data represent the mean \pm standard deviation. ${ }^{* *} \mathrm{P}<0.01$ vs. the control group.

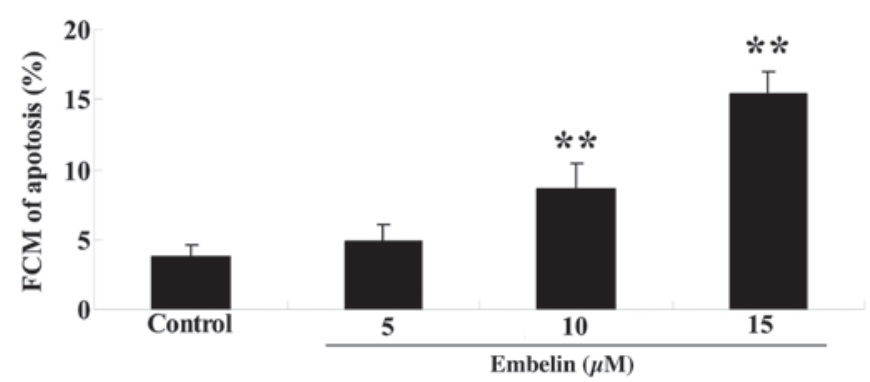

Figure 4. Effect of embelin on cell apoptosis of gastric carcinoma cells Data represent the mean \pm standard deviation. ${ }^{* *} \mathrm{P}<0.01$ vs. the control group. FCM, flow cytometry.

To investigate the anticancer effect of embelin on tumor growth, SGC7901 cells were treated with embelin $(5,10$ or $15 \mu \mathrm{M})$ for 1,3 or 5 days, and the levels of cell proliferation were determined using the MTT assay. As demonstrated in Fig. 2, 10 and $15 \mu \mathrm{M}$ embelin significantly suppressed cell proliferation following 5-days of culture, compared with the control group $(\mathrm{P}<0.01)$. Therefore, further assays were performed on SGC7901 cells treated with the various concentrations of embelin for 5 days.

Embelin induces caspase-3 activity in gastric carcinoma cells. To investigate the therapeutic effect of embelin on cell apoptosis, SGC7901 cells were treated with embelin (5, 10 and $15 \mu \mathrm{M})$ for 4 days, and caspase-3 activity was measured. As demonstrated in Fig. 3, 10 or $15 \mu \mathrm{M}$ embelin significantly increased caspase- 3 activity compared with the control group $(\mathrm{P}<0.01)$.
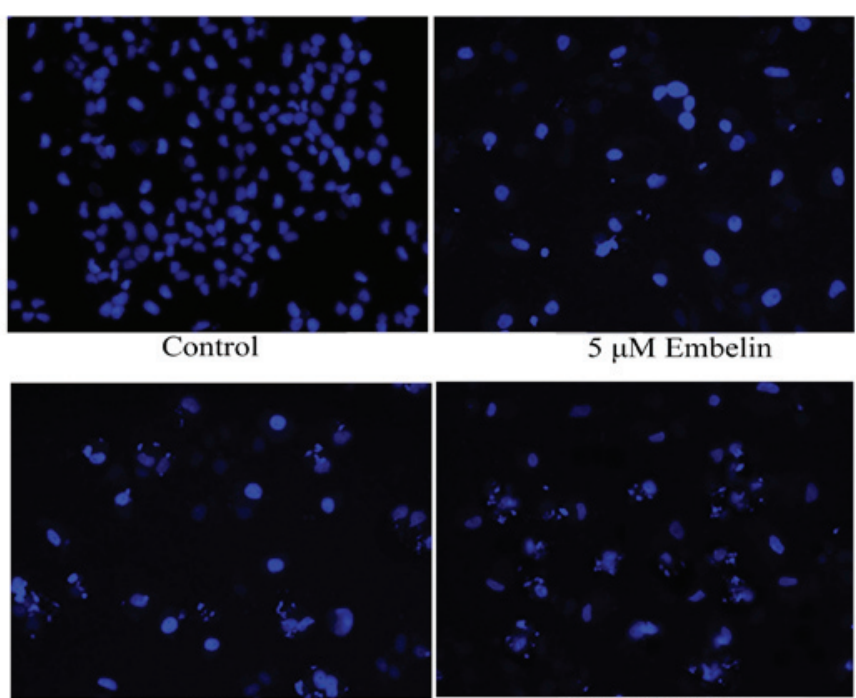

$10 \mu \mathrm{M}$ Embelin

$15 \mu \mathrm{M}$ Embelin

Figure 5. Effect of embelin on nuclear apoptosis in gastric carcinoma cells

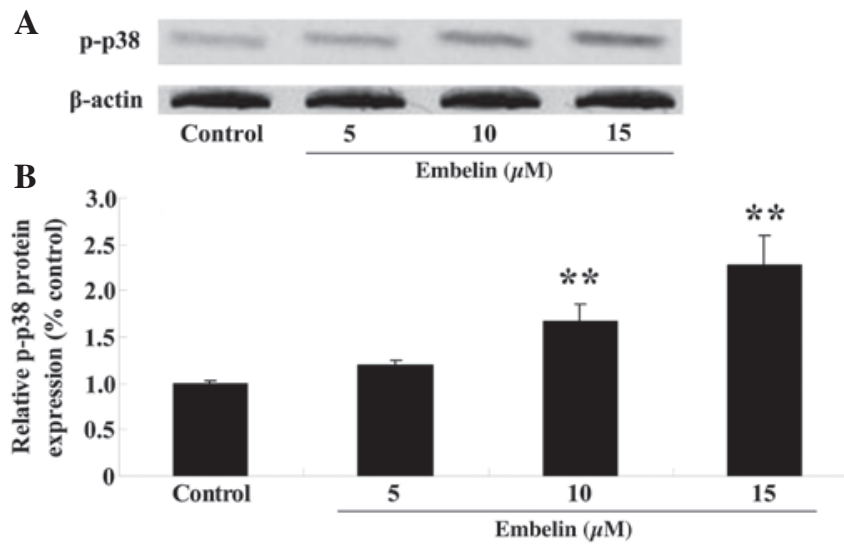

Figure 6. Effect of embelin on p-p38 MAPK protein expression in gastric carcinoma cells. (A) Western blotting assay and (B) quantification of immunoblot. Data represent the mean \pm standard deviation. ${ }^{* *} \mathrm{P}<0.01$ vs. the control group.

Embelin induces cellular apoptosis in gastric carcinoma cells. In order to examine the effect of embelin on cell apoptosis, SGC7901 cells were treated with embelin $(5,10$ or $15 \mu \mathrm{M})$ for 4 days, and the cellular apoptosis was determined. As demonstrated in Fig. 4, 10 and $15 \mu \mathrm{M}$ embelin significantly increased the percentage of cellular apoptosis compared with the control group $(\mathrm{P}<0.01)$.

Effect of embelin induces nuclear apoptosis in gastric carcinoma cells. In order to investigate the anticancer effect of embelin on nuclear apoptosis, SGC7901 cells were treated with 5,10 or $15 \mu \mathrm{M}$ embelin for 4 days, and nuclear apoptosis was evaluated with the DAPI staining assay. As demonstrated in Fig. 5, nuclear apoptosis was observed following embelin treatment at all concentrations.

Embelin induces p-p38 MAPK protein expression levels in gastric carcinoma cells. SGC7901 cells were treated with embelin $(5,10$ or $15 \mu \mathrm{M})$ for 4 days, and the p-p38 MAPK protein expression levels were measured using western 


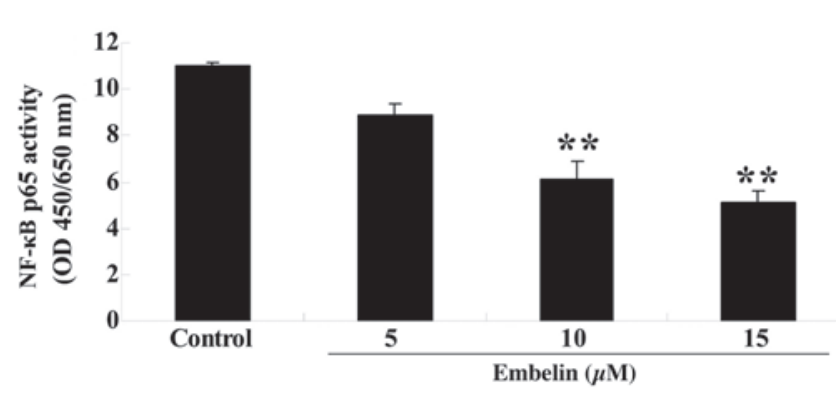

Figure 7. Effect of embelin on the NF- $\kappa \mathrm{B}$ p65 activity in gastric carcinoma cells. Data represent the mean \pm standard deviation. ${ }^{* *} \mathrm{P}<0.01$ vs. the control group. NF- $\kappa \mathrm{B}$, nuclear factor $\kappa \mathrm{B}$.

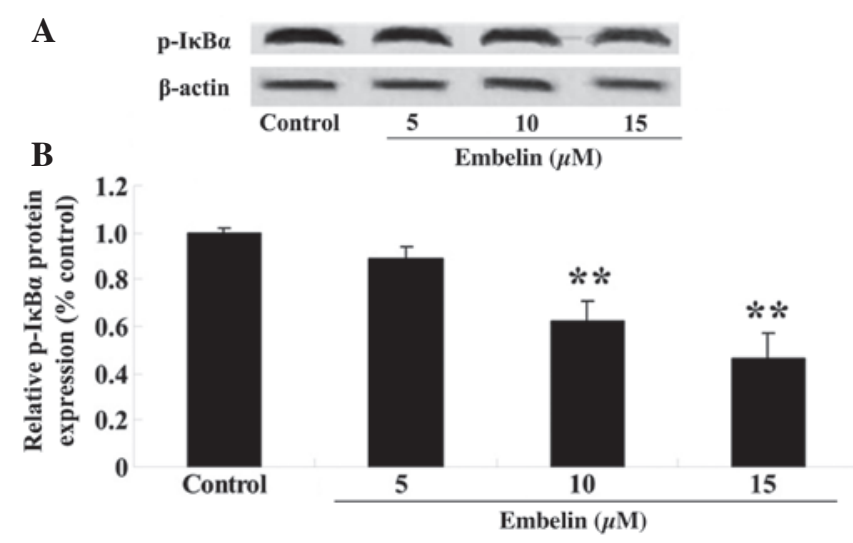

Figure 8. Effect of embelin on the phosphorylated $\mathrm{I} \kappa \mathrm{B} \alpha$ protein expression levels in gastric carcinoma cells. (A) Western blot assay and (B) quantification of immunoblot. Data represent the mean \pm standard deviation.

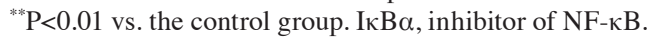

blotting. The results demonstrated that administration of embelin treatment (10 or $15 \mu \mathrm{M})$ significantly upregulated the relative p-p38 MAPK protein expression levels compared with those of the control group ( $\mathrm{P}<0.01$; Fig. 6).

Embelin inhibits $N F-\kappa B$ p65 activity in gastric carcinoma cells. SGC7901 cells were treated with embelin $(5,10$ or $15 \mu \mathrm{M})$ for 4 days, and the NF- $\mathrm{B}$ p65 activity was measured. As demonstrated in Fig. 7, embelin treatment $(10$ or $15 \mu \mathrm{M})$ significantly reduced NF- $\kappa \mathrm{B}$ p65 activity compared with the control group $(\mathrm{P}<0.01)$.

Embelin inhibits the phosphorylation of $I \kappa B \alpha$ in gastric carcinoma cells. SGC7901 cells were treated with embelin $(5,10$ or $15 \mu \mathrm{M})$ for 4 days, and the $\mathrm{p}-\mathrm{I} \kappa \mathrm{B} \alpha$ expression levels relative to $\beta$-actin were determined with western blotting. As demonstrated in Fig. 8, embelin treatment (10 or $15 \mu \mathrm{M})$ significantly suppressed $\mathrm{p}$-I $\mathrm{I} \mathrm{B} \alpha$ protein expression compared with the control group $(\mathrm{P}<0.01)$.

Embelin inhibits the phosphorylation of the IKK $\alpha / \beta$ in gastric carcinoma cells. To investigate the anticancer therapeutic effect of embelin treatment on IKK $\alpha / \beta$ protein expression, SGC7901 cells were treated with embelin $(5,10$ or $15 \mu \mathrm{M})$ for 4 days, and the $\mathrm{p}$-IKK $\alpha / \beta$ protein expression levels relative to $\beta$-actin were determined with western blotting. As demonstrated in Fig. 9, embelin treatment (10 or $15 \mu \mathrm{M})$

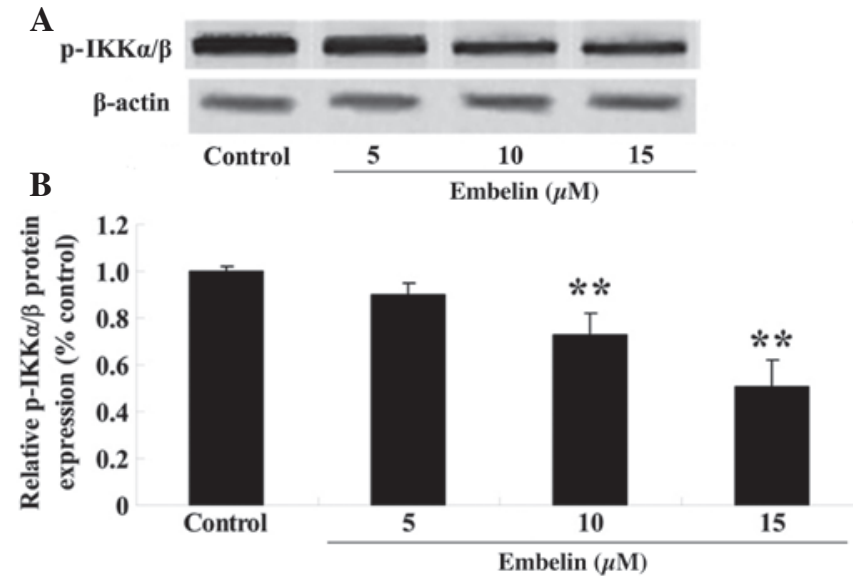

Figure 9. Effect of embelin on the phosphorylated IKK $\alpha / \beta$ protein expression levels in gastric carcinoma cells. (A) Western blotting assay and (B) quantification of immunoblot. Data represent the mean \pm standard deviation. ${ }^{* *} \mathrm{P}<0.01$ vs. the control group. IKK $\alpha / \beta$, IкB kinase $\alpha / \beta$.

significantly reduced the relative $\mathrm{p}-\mathrm{IKK} \alpha / \beta$ protein expression levels compared with the control group $(\mathrm{P}<0.01)$.

\section{Discussion}

Malignant tumors are the second leading cause of mortality in China, and stomach cancer presents the highest rate of mortality associated with these tumors (13). China has the highest rate of gastric carcinoma worldwide (14) and the rate has risen over the past 20 years (15). In the present study, embelin treatment significantly suppressed cell proliferation, induced caspase-3 activation, and increased cell and nuclear apoptosis in the SGC7901 cells. Marsh et al (16) suggested that embelin suppresses the growth of pancreatic cancer in A549 non-small cell lung cancer (17) and brain glioma cells (18). Embelin is considered to be a potential drug for the treatment of carcinoma.

MAPKs are Ser/Thr protein kinases that mediate the cellular response and apoptosis, react to various cell growth and mitosis promotion factors, and transduct outer signals into cells (19). The signal transmission of the MAPK pathway is completed by the continuous phosphorylation of MAPKKK, MAPKK and MAPK (20). There are five activators of the MAPK pathways; ERK, p38, JNK, ERK3/ERK4 and ERK5 (21). Extracellular stimuli result in different biological responses depending on the MAPK pathway activated (22). In the present study, administration of embelin significantly upregulated the relative p38 MAPK protein expression in human gastric carcinoma cells. Wang et al (23) indicated that embelin reduced cell viability in gastric cancer cells via p38 MAPK pathway activation. Avisetti et al (24) indicated that embelin induced apoptosis in lung cancer cells through the activation of the $\mathrm{p} 38 / \mathrm{JNK}$ pathway. Activation of the $\mathrm{p} 38 / \mathrm{JNK}$ pathway may be a potential target for embelin treatment in human gastric carcinoma cells.

The occurrence and development of a tumor is a complex and multistep process that involves a series of genetic changes, including metastasis of cells deriving from the primary tumor into the blood and lymphatic vessels, through adhesion to endothelial cells, resulting in the metastasis of the tumor (25). A previous study demonstrated that the upregulation of $N F-\kappa B$ leads to the occurrence of tumors, and NF- $\mathrm{B}$ mediates 
one of the main mechanisms by which tumor cells resist apoptosis during tumor development (26). Upon activation, it produces anti-apoptotic signals to aid the development of the tumor. Royuela et al (27) demonstrated that NF- $\kappa \mathrm{B}$ induces anti-apoptosis genes, including IAG, cl-2 like factor, TRAF1, TRAF2 and A20D. Similarly, NF- $\kappa$ B promotes tumor formation via a non-apoptotic pathway, activating the proto-oncogenes $c$-myc and cyclin D1 (28). Yang et al (28) demonstrated that cyclin D1 was the target gene of $N F-\kappa B$, and that $N F-\kappa B$ initiated the transcription of cyclin $\mathrm{D} 1$, promoting the transit from phase $G_{1} / G_{0}$ to phase $S$, leading to the cell proliferation, malignant transformation and cancerization (29). In the present study, embelin significantly reduced the $N F-\kappa B$ activity in human gastric carcinoma cells. Ahn et al (30) indicated that embelin is a potential suppressor of tumorigenesis, as it suppresses NF-кB-regulated anti-apoptosis. Reuter et al (12) demonstrated that embelin suppresses osteoclastogenesis through the inhibition of the NF- $\mathrm{NB}$ cell signaling pathway. Therefore, the suppression of $\mathrm{NF}-\kappa \mathrm{B}$ may be a marker for embelin treatment in human gastric carcinoma cells.

Pathological classification of the tumor may indicate its invasiveness, thus, NF- $\mathrm{B}$ p65 activity may have an effect on tumor metastasis (31). NF- $\kappa \mathrm{B}$ serves a role in the activation of the immune system, cell apoptosis and inflammatory cell chemotaxis associated with gene transcription. As a gene encoding inflammatory molecules, $\mathrm{NF}-\kappa \mathrm{B}$ regulates and controls the expression of numerous inflammation-mediating genes, and $\mathrm{NF}-\kappa \mathrm{B}$ p65 activation was previously associated with cell infiltration $(32,33)$. In the present study, a significant reduction in the relative $\mathrm{p}-\mathrm{I} \kappa \mathrm{B} \alpha$ and $\mathrm{p}-\mathrm{IKK} \alpha / \beta$ protein expression levels was observed following embelin treatment (10 or $15 \mu \mathrm{M})$. Park et al (34) indicated that the administration of embelin induced apoptosis in human glioma cells through the degradation of $\mathrm{p}-\mathrm{I} \kappa \mathrm{B} \alpha$ and $\mathrm{p}-\mathrm{IKK} \alpha / \beta$. This may have been due to the decrease in $\mathrm{p}-\mathrm{I} \kappa \mathrm{B} \alpha$ and $\mathrm{p}-\mathrm{IKK} \alpha / \beta$ protein expression induced by embelin treatment.

In conclusion, the results of the current study suggest that embelin suppresses cell proliferation and induces levels of apoptosis in human gastric carcinoma cells through the inhibition of the NF- $\kappa \mathrm{B}$ signaling pathway. These results indicate that the suppression of the $\mathrm{NF}-\kappa \mathrm{B}$ signaling pathway, due to embelin administration, is a potential therapeutic target for the treatment of gastric carcinoma.

\section{References}

1. Lam TK, Freedman ND, Fan JH, Qiao YL, Dawsey SM, Taylor PR and Abnet CC: Prediagnostic plasma vitamin C and risk of gastric adenocarcinoma and esophageal squamous cell carcinoma in a Chinese population. Am J Clin Nutr 98: 1289-1297, 2013

2. Philips P, North DA, Scoggins C, Schlegel M and Martin RC: Gastric-Esophageal Stenting for Malignant Dysphagia: Results of Prospective Clinical Trial Evaluation of Long-Term Gastroesophageal Reflux and Quality of Life-Related Symptoms. J Am Coll Surg 221: 165-173, 2015.

3. Zhang DS, Jin Y, Luo HY, Wang ZQ, Qui M, Wang FH, Li Y and Xu RH: Pemetrexed for previously treated patients with metastatic gastric cancer: A prospective phase II study. Br J Cancer 112 266-270, 2015.

4. Zhang L, Ding Y, Yuan Z, Liu J, Sun J, Lei F, Wu S, Li S and Zhang D: MicroRNA-500 sustains nuclear factor- $\kappa$ B activation and induces gastric cancer cell proliferation and resistance to apoptosis. Oncotarget 6: 2483-2495, 2015.
5. Chandrasekar B, Mummidi S, Perla RP, Bysani S, Dulin NO, Liu F and Melby PC: Fractalkine (CX3CL1) stimulated by nuclear factor kappaB (NF-kappaB)-dependent inflammatory signals induces aortic smooth muscle cell proliferation through an autocrine pathway. Biochem J 373: 547-558, 2003.

6. Zhu BS, Xing CG, Lin F, Fan XQ, Zhao K and Qin ZH: Blocking $\mathrm{NF}-\kappa \mathrm{B}$ nuclear translocation leads to p53-related autophagy activation and cell apoptosis. World J Gastroenterol 17: 478-487, 2011.

7. Shostak K and Chariot A: EGFR and NF-kB: Partners in cancer. Trends Mol Med 21: 385-393, 2015.

8. Mukherjee N, Houston TJ, Cardenas E and Ghosh R: To be an ally or an adversary in bladder cancer: The NF-kB story has not unfolded. Carcinogenesis 36: 299-306, 2015.

9. Li ZM, Pu YW and Zhu BS: Blockade of NF-кB nuclear translocation results in the inhibition of the invasiveness of human gastric cancer cells. Oncol Lett 6: 432-436, 2013.

10. Bai Y, Ahmad U, Wang Y, Li JH, Choy JC, Kim RW, Kirkiles-Smith N, Maher SE, Karras JG, Bennett CF, et al: Interferon-gamma induces X-linked inhibitor of apoptosis-associated factor-1 and Noxa expression and potentiates human vascular smooth muscle cell apoptosis by STAT3 activation. J Biol Chem 283: 6832-6842, 2008.

11. Hu R, Zhu K, Li Y, Yao K, Zhang R, Wang H, Yang W and Liu Z: Embelin induces apoptosis through down-regulation of XIAP in human leukemia cells. Med Oncol 28: 1584-1588, 2011.

12. Reuter S, Prasad S, Phromnoi K, Kannappan R, Yadav VR and Aggarwal BB: Embelin suppresses osteoclastogenesis induced by receptor activator of NF- $\kappa \mathrm{B}$ ligand and tumor cells in vitro through inhibition of the NF- $\mathrm{KB}$ cell signaling pathway. Mol Cancer Res 8: 1425-1436, 2010.

13. Xu ZJ, Zheng RS, Zhang SW, Zou XN and Chen WQ: Nasopharyngeal carcinoma incidence and mortality in China in 2009. Chin J Cancer 32: 453-460, 2013.

14. Guo W, Ou G, Li X, Huang J, Liu J and Wei H: Screening of the nutritional risk of patients with gastric carcinoma before operation by NRS 2002 and its relationship with postoperative results. J Gastroenterol Hepatol 25: 800-803, 2010.

15. Chen W, Zheng R, Zeng H, Zhang S and He J: Annual report on status of cancer in China, 2011. Chin J Cancer Res 27: 2-12, 2015.

16. Marsh JL, Jackman CP, Tang SN, Shankar S and Srivastava RK: Embelin suppresses pancreatic cancer growth by modulating tumor immune microenvironment. Front Biosci (Landmark Ed) 19: 113-125, 2014.

17. Jiang L, Hao JL, Jin ML, Zhang YG and Wei P: Effect of Embelin on TRAIL receptor $2 \mathrm{mAb}$-induced apoptosis of TRAIL-resistant A549 non-small cell lung cancer cells. Asian Pac J Cancer Prev 14: 6115-6120, 2013.

18. Wang A, Zhang B, Zhang J, Wu W and Wu W: Embelin-induced brain glioma cell apoptosis and cell cycle arrest via the mitochondrial pathway. Oncol Rep 29: 2473-2478, 2013.

19. Betti M, Ciacci C, Lorusso LC, Canonico B, Falcioni T, Gallo G and Canesi L: Effects of tumour necrosis factor alpha (TNFalpha) on Mytilus haemocytes: Role of stress-activated mitogen-activated protein kinases (MAPKs). Biol Cell 98: 233-244, 2006

20. Fiedler B, Feil R, Hofmann F, Willenbockel C, Drexler H, Smolenski A, Lohmann SM and Wollert KC: cGMP-dependent protein kinase type I inhibits TAB1-p38 mitogen-activated protein kinase apoptosis signaling in cardiac myocytes. J Biol Chem 281: 32831-32840, 2006.

21. Lei YY, Wang WJ, Mei JH and Wang CL: Mitogen-activated protein kinase signal transduction in solid tumors. Asian Pac J Cancer Prev 15: 8539-8548, 2014.

22. Shan X, Aziz F, Tian LL, Wang XQ, Yan Q and Liu JW: Ginsenoside Rg3-induced EGFR/MAPK pathway deactivation inhibits melanoma cell proliferation by decreasing FUT4/LeY expression. Int J Oncol 46: 1667-1676, 2015.

23. Wang DG, Sun YB, Ye F, Li W, Kharbuja P, Gao L, Zhang DY and Suo J: Anti-tumor activity of the X-linked inhibitor of apoptosis (XIAP) inhibitor embelin in gastric cancer cells. Mol Cell Biochem 386: 143-152, 2014.

24. Avisetti DR, Babu KS and Kalivendi SV: Activation of p38/JNK pathway is responsible for embelin induced apoptosis in lung cancer cells: Transitional role of reactive oxygen species. PLoS One 9: e87050, 2014.

25. Ren S, Abuel-Haija M, Khurana JS and Zhang X: D2-40: An additional marker for myoepithelial cells of breast and the precaution in interpreting tumor lymphovascular invasion. Int J Clin Exp Pathol 4: 175-182, 2011. 
26. Wang Y, Ma W and Zheng W: Deguelin, a novel anti-tumorigenic agent targeting apoptosis, cell cycle arrest and anti-angiogenesis for cancer chemoprevention. Mol Clin Oncol 1: 215-219, 2013.

27. Royuela M, Rodriguez-Berriguete G, Fraile B and Paniagua R TNF-alpha/IL-1/NF-kappaB transduction pathway in human cancer prostate. Histol Histopathol 23: 1279-1290, 2008.

28. Yang GF, Deng CS, Xiong YY, Gong LL, Wang BC and Luo J: Expression of nuclear factor-kappa B and target genes in gastric precancerous lesions and adenocarcinoma: Association with Helicobactor pylori cagA (+) infection. World J Gastroenterol 10: 491-496, 2004

29. Janjetovic Z, Tuckey RC, Nguyen MN, Thorpe EM Jr and Slominski AT: 20,23-dihydroxyvitamin D3, novel P450scc product, stimulates differentiation and inhibits proliferation and NF-kappaB activity in human keratinocytes. J Cell Physiol 223: 36-48, 2010.

30. Ahn KS, Sethi G and Aggarwal BB: Embelin, an inhibitor of $\mathrm{X}$ chromosome-linked inhibitor-of-apoptosis protein, blocks nuclear factor-kappaB (NF-kappaB) signaling pathway leading to suppression of NF-kappaB-regulated antiapoptotic and metastatic gene products. Mol Pharmacol 71: 209-219, 2007.
31. Kwon HC, Kim SH, Oh SY, Lee S, Lee JH, Jang JS, Kim MC, Kim KH, Kim SJ, Kim SG and Kim HJ: Clinicopathologic significance of expression of nuclear factor- $\kappa \mathrm{B}$ RelA and its target gene products in gastric cancer patients. World J Gastroenterol 18: 4744-4750, 2012.

32. Sousa LP, Carmo AF, Rezende BM, Lopes F, Silva DM, Alessandri AL, Bonjardim CA, Rossi AG, Teixeira MM and Pinho V: Cyclic AMP enhances resolution of allergic pleurisy by promoting inflammatory cell apoptosis via inhibition of PI3K/Akt and NF-kappaB. Biochem Pharmacol 78: 396-405, 2009.

33. Fischer CD, Beatty JK, Zvaigzne CG, Morck DW, Lucas MJ and Buret AG: Anti-Inflammatory benefits of antibiotic-induced neutrophil apoptosis: Tulathromycin induces caspase-3-dependent neutrophil programmed cell death and inhibits NF-kappaB signaling and CXCL8 transcription. Antimicrob Agents Chemother 55: 338-348, 2011.

34. Park SY, Lim SL, Jang HJ, Lee JH, Um JY, Kim SH, Ahn KS and Lee SG: Embelin induces apoptosis in human glioma cells through inactivating NF-кB. J Pharmacol Sci 121: 192-199, 2013. 